\title{
Peningkatan Hasil Belajar PKn melalui Pembelajaran Kooperatif Tipe Group Investigation pada Murid Kelas IV SD Inpres Boronguntia Kecamatan Bajeng Kabupaten Gowa
}

\author{
Muhajir ${ }^{1)}$ \& Andi Auliah Rukman ${ }^{2)}$ \\ Pendidikan Pancasila dan Kewarganegaraan FKIP Universitas Muhammadiyah Makassar ${ }^{1)}$ \\ Pendidikan Pancasila dan Kewarganegaraan FKIP Universitas Muhammadiyah Makassar ${ }^{2)}$ \\ muhajir@unismuh.ac.id $d^{1)} \&$ andiauliahrukman@unismuh.ac.id ${ }^{2)}$
}

\begin{abstract}
This study aims to improve the learning outcomes of Citizenship Education through the implementation of the Group Investigation learning model in fourth grade students of Inpres Boronguntia Subdistrict Bajeng District of Gowa Regency. Subjects in this study were fourth graders Inpres Boronguntia District Bajeng District Gowa regency as many as 17 people consisting of 10 men and 7 women. This type of research is a classroom action research consisting of two cycles in which each cycle is held for four meetings. Each cycle consists of 4 stages: planning, action, observation and reflection. Data collection techniques used are observations and test results of learning are analyzed by quantitative and qualitative analysis techniques. The results showed that in the first fully completed cycle of 17 students only 5 students or $29.41 \%$ who fulfilled the Minimum Exhaustiveness Criteria (KKM) with an average score of 56.47 or in the medium category. While in the second complete cycle of 17 students is 13 students or $76.47 \%$ who meet the Minimum Exhaustiveness Criteria (KKM) with an average value obtained for 86.67 or are in very high category.

Keywords: Learning Model, Group Investigation, Learning Outcomes, Citizenship Education
\end{abstract}

Abstrak. Penelitian ini bertujuan untuk meningkatkan hasil belajar Pendidikan Kewarganegaraan melalui penerapan model pembelajaran Group Investigation pada murid kelas IV SD Inpres Boronguntia Kecamatan Bajeng Kabupaten Gowa. Subjek dalam penelitian ini adalah murid kelas IV SD Inpres Boronguntia Kecamatan Bajeng Kabupaten Gowa sebanyak 17 orang terdiri dari 10 laki-laki dan 7 perempuan. Jenis penelitian ini adalah penelitian tindakan kelas (Clasroom Action Research) yang terdiri dari dua siklus di mana setiap siklus dilaksanakan sebanyak empat kali pertemuan. Setiap siklus terdiri dari 4 tahap, yaitu: perencanaan, tindakan, observasi dan refleksi. Teknik pengumpulan data yang digunakan adalah observasi dan Tes hasil belajar yang dianalisis dengan teknik analisis kuantitatif dan kualitatif. Hasil penelitian menunjukkan bahwa pada siklus pertama yang tuntas secara individual dari 17 murid hanya 5 murid atau 29,41\% yang memenuhi Kriteria Ketuntasan Minimal (KKM) dengan nilai rata-rata yang diperoleh sebesar 56,47 atau berada pada kategori sedang. Sedangkan pada siklus kedua yang tuntas dari 17 murid adalah 13 murid atau 76,47\% yang memenuhi Kriteria Ketuntasan Minimal (KKM) dengan nilai rata-rata yang diperoleh sebesar 86,67 atau berada pada kategori sangat tinggi.

Kata kunci: Model Pembelajaran, Group Investigation, Hasil Belajar, Pendidikan Kewarganegaraan 


\section{PENDAHULUAN}

Dengan penerapan model pembelajaran Group Investigation (GI) diharapkan akan terjadi peningkatan hasil belajar PKn dengan KKM 65. Untuk mencapai KKM tersebut guru diharapkan terampil menggunakan model pembelajaran inovatif. Model Group Investigation (GI) adalah merupakan salah satu bentuk model pembelajaran inovatif yang menekankan pada partisipasi untuk mencari sendiri materi pelajaran yang akan dipelajari melalui bahan yang tersedia.

Undang-Undang No.20 Tahun 2003 tentang Sistem Pendidikan Nasional menyatakan bahwa pendidikan adalah usaha sadar dan terencana untuk mewujudkan suasana belajar dan proses pembelajaran agar peserta didik secara aktif mengembangkan potensi dirinya untuk memiliki kekuatan spiritual keagamaan, pengendalian diri, kepribadian, kecerdasan, akhlak mulia, serta keterampilan yang diperlukan dirinya, masyarakat, bangsa, dan negara.Terdapat beberapa hal yang sangat penting untuk kita kritisi dari konsep pendidikan menurut undang-undang tersebut.

Pertama, pendidikan adalah usaha sadar yang terencana, hal ini berarti proses pendidikan di sekolah bukanlah proses yang dilaksanakan secara asal-asalan dan untung-untungan, akan tetapi proses yang bertujuan sehingga segala sesuatu yang dilakukan guru dan murid diarahkan pada pencapaian tujuan.

Kedua, proses pendidikan yang terencana itu diarahkan untuk mewujudkan suasana belajar dan proses pembelajaran, hal ini berarti pendidikan tidak boleh mengesampingkan proses belajar. Pendidikan tidak semata-mata berusaha untuk mencapai hasil belajar, akan tetapi bagaimana memperoleh hasil atau proses belajar yang terjadi pada diri anak. Dengan demikian, dalam pendidikan antara proses dan hasil belajar harus berjalan secara seimbang. Pendidikan yang hanya mementingkan salah satu di antaranya tidak akan dapat membentuk manusia yang berkembang secara utuh.

Ketiga, suasana belajar dan pembelajaran itu diarahkan agar peserta didik dapat mengembangkan potensi dirinya, ini berarti proses pendidikan itu harus berorientasi kepada siswa (student active learning). Pendidikan adalah upaya pengembangan potensi anak didik. Dengan demikian, anak harus dipandang sebagai organisme yang sedang berkembang dan memiliki potensi. Tugas pendidikan adalah mengembangkan potensi yang dimiliki anak didik, bukan menjejalkan materi pelajaran atau memaksa agar anak dapat menghafal data dan fakta.

Keempat, akhir dari proses pendidikan adalah kemampuan anak memiliki kekuatan spiritual keagamaan, pengendalian diri, kepribadian, kecerdasan, akhlak mulia, serta keterampilan yang diperlukan dirinya, masyarakat, bangsa, dan negara. Hal ini berarti proses pendidikan berujung kepada pembentukan keterampilan anak sesuai dengan kebutuhan. Ketiga aspek inilah (sikap, kecerdasan, dan keterampilan) arah dan tujuan pendidikan yang harus diupayakan, (Sanjaya, 2006:2-3).

Persoalan pendidikan yang senantiasa timbul ialah adanya ketidak seimbangan antara apa yang dapat dicapai oleh pendidikan dengan tuntutan objektif masyarakat. Masyarakat senantiasa menuntut operasi pendidikan yang lebih efektif. Tuntutan ini merupakan tantangan bagi kita, kaum pendidik, untuk merubah cara berfikir dan cara bekerja yang sudah tidak sesuai lagi. Perubahan lingkungan menuntut perubahan cara pendekatan, dan kita harus mengadakan perubahan-perubahan pula dalam pengelolaan dan pelaksanaan pendidikan. Sebelumnya kita mengadakan perubahan, seyogyanyalah kita membuat perencanaan yang matang.

Pendidikan Kewarganegaraan (Citizenship) merupakan mata pelajaran yang memfokuskan pada pembentukan diri yang beragam dari segi agama, sosio-kultural, bahasa, usia, dan suku bangsa untuk menjadi warga negara yang cerdas, terampil, dan berkarakter yang diamanatkan oleh Pancasila dan UUD 1945.

Salah satu masalah yang dihadapi dunia pendidikan adalah masih lemahnya proses pembelajaran. Dalam proses pembelajaran, anak kurang didorong untuk mengembangkan kemampuan berfikir. Proses pembelajaran di dalam 
kelas diarahkan kepada kemampuan anak untuk menghafal informasi, otak anak dipaksa untuk mengingat dan menimbun berbagai informasi tanpa dituntut untuk mamahami informasi yang diingatnya itu untuk menghubungkannya dengan kehidupan sehari-hari.

Sekolah Dasar (SD) sampai saat ini masih jauh dari apa yang kita harapkan. Maka dari itu penulis merasa sangat tertarik dan perlu mengadakan penelitian lebih lanjut dengan harapan dapat mengetahui lebih dalam mengenai upaya peningkatan hasil belajar murid dalam pembelajaran PKn melalui pembelajaran kooperatif tipe investigasi kelompok (group investigation) pada SD Inpres Boronguntia Kecamaatan Bajeng Kabupaten Gowa. Melihat kondisi rendahnya hasil belajar murid tersebut beberapa upaya yang dilakukan salah satunya adalah pemberian tugas kepada murid. Dengan pemberian tugas kelompok dengan menggunakan model pembelajaran tipe investigasi kelompok (group investigation) kepada murid diharapkan dapat meningkatkan hasil belajarnya, sehingga terjadi pengulangan dan penguatan terhadap materi yang diberikan di sekolah dengan harapan murid mampu meningkatkan hasil belajar.

Berdasarkan observasi yang dilakukan kepada murid kelas IV SD Inpres Boronguntia Kecamatan Bajeng Kabupaten Gowa terungkap bahwa rata-rata nilai pelajaran PKn adalah 53,82\% dengan kriteria ketuntasan minimal (KKM) 65. Adapuan hasil tes awal ini diikuti siswa sebanyak 17 terungkap bahwa, dimana siswa yang tuntas dalam mengikuti pelajaran 5 orang atau 20,29\% dan yang belum tuntas 12 orang atau $33,53 \%$.

Adapun penyebab rendahnya hasil belajar dan prestasi murid tersebut pada mata pelajaran PKn adalah guru hanya cenderung menggunakan metode ceramah, sehingga murid kurang memiliki kesempatan untuk belajar kelompok. Di samping itu juga guru kurang melibatkan murid secara aktif pada lingkungan belajar serta kurang menggunakan model pembelajaran, di mana guru lebih mendominasi metode ceramah tanpa memberikan kesempatan kepada murid untuk melakukan belajar kelompok dengan menggunakan model pembelajaran sehingga murid kurang termotivasi dalam proses pembelajaran. Untuk memecahkan masalah di atas maka diperlukan pembelajaran dengan model pembelajaran yaitu model pembelajaran kooperatif tipe investigasi kelompok sebagai alternatif tindakan dalam peningkatan hasil belajar PKn melalui pembelajaran kooperatif tipe investigasi kelompok pada murid kelas IV SD Inpres Boronguntia Kecamatan Bajeng Kabupaten Gowa. Pemilihan model pembelajaran tipe investigasi kelompok adalah untuk mengutamakan kreativitas murid, murid memilih topik untuk diselidiki, melakukan penyelidikan yang mendalam atas topik yang dipilih itu. Selanjutnya menyiapkan laporan dan mempresentasikan laporannya kepada seluruh kelas agar hasil belajar murid meningkat lebih efektif dan efisien sehingga model tersebut cocok diterapkan pada mata pelajaran PKn. Oleh karena itu, peneliti bermaksud untuk mengatasi masalah tersebut dalam bentuk penelitian tindakan kelas (PTK).

\section{METODE PENELITIAN}

Penelitian ini merupakan penelitian tindakan kelas (classroom action research). Penelitian ini dilaksanakan di SD Inpres Boronguntia Kecamatan Bajeng Kabupaten Gowa. Subjek penelitian ini adalah murid kelas IV SD Inpres Boronguntia Kecamatan Bajeng Kabupaten Gowa, dengan jumlah murid 17 orang yang terdiri dari 10 orang laki-laki dan 7 orang perempuan. Rancangan penelitian tindakan kelas yang dilaksanakan terdiri atas dua siklus, yakni siklus pertama dan siklus kedua. Siklus pertama terdiri atas lima kali pertemuan, empat kali pemberian materi dan satu kali evaluasi begitu pula siklus kedua. Dalam satu siklus pada penelitian tindakan kelas terdiri dari beberapa kegiatan, yaitu perencanaan, tindakan, observasi, dan refleksi. Kegiatan-kegiatan pada siklus kedua merupakan pengulangan dan perbaikan dari kegiatan pada siklus pertama.

Instrumen yang digunakan dalam penelitian ini adalah Rencana Pelaksanaan Pembelajaraan, tes tertulis dan nontes. Tes tersebut bersumber dari materi yang telah dijelaskan oleh guru selama proses pembelajaran. Tes tersebut diberikan pada 
akhir setiap siklus. Selain itu, digunakan pula instrumen penelitian dalam bentuk nontes berupa lembar observasi yang terdiri atas lembar observasi aktivitas murid dan lembar observasi aktivitas guru.

Untuk memperoleh data dan informasi yang dibutuhkan, maka teknik pengumpulan data yang digunakan dalam penelitian ini adalah (a) Observasi merupakan teknik mengumpulkan data dengan cara mengamati setiap kejadian yang sedang berlangsung dan mencatatnya dengan alat observasi tentang hal-hal yang akan diamati atau diteliti. Tes hasil belajar. Tujuannya untuk mengetahui peningkatan hasil belajar murid antara sebelumnya dan sesudah pemberian tindakan, diawali dengan menentukan aspek-aspek yang akan diteliti, dan dilanjutkan dengan pemberian skor. Data yang terkumpul dianalisis dengan menggunakan teknik analisis kuantitatif dan kualitatif. Untuk analisis kuantitatif digunakan statistik deskriptif, yaitu rata-rata dan persentase, tabel frekuensi, persentase nilai terendah dan tertinggi. Untuk analisis kuantitatif digunakan teknik kategorisasi tingkat penguasaan materi. Kategorisasi yang digunakan untuk menentukan kategori skor adalah teknik kategorisasi standar berdasarkan ketetapan Depdiknas (2006).

Tabel 2 Distribusi Frekuensi Skor

\begin{tabular}{lll}
\hline No. & Interval & Kategori Hasil Belajar \\
\hline 1. & $16-32$ & Sangat rendah \\
\hline 2. & $33-49$ & Rendah \\
\hline 3. & $50-66$ & Sedang \\
\hline 4. & $67-83$ & Tinggi \\
\hline 5. & $84-100$ & Sangat tinggi \\
\hline
\end{tabular}

Sumber: Depdiknas (2006)

Rumus Teknik Analisis Data

Rumus : $P=\frac{f}{N} \times 100 \%$

Keterangan :

$\mathrm{P}=$ Persen

$f=$ Frekuensi

$N=\sum$ responden

Data hasil belajar murid berupa tes juga dianalisis secara kuantitatif dengan menggunakan Standar Ketuntasan Belajar Minimum (SKBM) yang ditetapkan oleh sekolah khususnya pada mata pelajaran PKn yaitu 65 ke atas dikategorikan tuntas dan untuk nilai di bawah 65 dikategorikan tidak tuntas. Indikator keberhasilan penelitian tindakan kelas ini adalah meningkatnya kualitas pembelajaran yang dapat dilihat dari dua segi yaitu kualitas proses dan kualitas hasil. Dari segi kualitas proses pembelajaran meliputi keaktifan fisik, mental, dan sosial. Sedangkan dari segi kualitas hasil dapat dilihat dari meningkatnya ketuntasan belajar murid. Hal ini dapat dilihat dari skor ratarata kelas yang diperoleh murid, yaitu mencapai ketuntasan perorangan jika murid memperoleh nilai minimal 65 dan ketuntasan klasikal tercapai jika minimal $85 \%$.

\section{PEMBAHASAN}

\section{Aktivitas Belajar Murid}

Data perubahan sikap dan perilaku belajar seperti keaktifan murid pada setiap siklus.

Tabel 3 Hasil observasi akivitas siklus I

\begin{tabular}{|c|c|c|c|c|c|c|c|}
\hline \multirow[b]{2}{*}{$\begin{array}{l}N \\
0\end{array}$} & \multirow[t]{2}{*}{ Aspek yang Diamati } & \multicolumn{4}{|c|}{ Pertemuan } & \multirow[t]{2}{*}{$\mathrm{R}$} & \multirow[t]{2}{*}{$\%$} \\
\hline & & I & II & III & IV & & \\
\hline 1. & $\begin{array}{l}\text { Murid yang duduk } \\
\text { berkelompok secara } \\
\text { heterogen }\end{array}$ & 3 & 3 & 3 & 3 & 3 & $\begin{array}{c}17,6 \\
4\end{array}$ \\
\hline 2. & $\begin{array}{l}\text { Murid yang } \\
\text { memperhatikan } \\
\text { penjelasan guru }\end{array}$ & 2 & 2 & 2 & 2 & 2 & $\begin{array}{c}11,7 \\
6\end{array}$ \\
\hline 3. & $\begin{array}{l}\text { Ketua kelompok } \\
\text { mengambil } \\
\text { materi/tugas } \\
\text { kelompok yang } \\
\text { berbeda dari } \\
\text { kelompok lain }\end{array}$ & 3 & 3 & 3 & 3 & 3 & $\begin{array}{c}17,6 \\
4\end{array}$ \\
\hline 4. & $\begin{array}{l}\text { Masing- masing } \\
\text { kelompok } \\
\text { membahas materi } \\
\text { yang sudah ada } \\
\text { secara kooperatif } \\
\text { dan bersifat } \\
\text { penemuan }\end{array}$ & 3 & 3 & 3 & 3 & 3 & $\begin{array}{c}17,6 \\
4\end{array}$ \\
\hline 5. & $\begin{array}{l}\text { Juru bicara } \\
\text { kelompok } \\
\text { menyampaikan hasil } \\
\text { pembahasan } \\
\text { kelompok }\end{array}$ & 2 & 2 & 2 & 2 & 2 & $\begin{array}{c}11,7 \\
6\end{array}$ \\
\hline 6. & $\begin{array}{l}\text { Murid } \\
\text { memperhatikan } \\
\text { penjelasan singkat } \\
\text { dan kesimpulan dari } \\
\text { guru }\end{array}$ & 4 & 4 & 4 & 4 & 4 & $\begin{array}{c}23,5 \\
3\end{array}$ \\
\hline 7. & $\begin{array}{l}\text { Murid yang } \\
\text { mengerjakan soal } \\
\text { evaluasi }\end{array}$ & 4 & 4 & 4 & 4 & 4 & $\begin{array}{c}23,5 \\
3\end{array}$ \\
\hline & Rat & rata & & & & & $\begin{array}{c}17,6 \\
4\end{array}$ \\
\hline
\end{tabular}

Ket : Petunjuk Pengisian

$$
\begin{aligned}
& 1=\text { Kurang } \\
& 2=\text { Cukup }
\end{aligned}
$$


$3=$ Baik

4 = Sangat Baik

Berdasarkan data pada tabel 3 diperoleh gambaran mengenai aktivitas belajar murid pada siklus I, dimana dari 17 murid kelas IV SD Inpres Boronguntia Kecamatan Bajeng Kabupaten Gowa yang diobservasi terkait aspek-aspek aktivitas belajar, hasilnya dapat dijelaskan dalam skala deskriptif sebagai berikut: Murid yang duduk berkelompok secara heterogen sebesar 17,64\%, Murid yang memperhatikan penjelasan guru sebesar 11,76\%, Ketua kelompok mengambil materi/tugas kelompok yang berbeda dari kelompok lain sebesar 17,64\%, Masing- masing kelompok membahas materi yang sudah ada secara kooperatif dan bersifat penemuan sebesar $17,64 \%$, Juru bicara kelompok menyampaikan hasil pembahasan kelompok sebesar $11,76 \%$, dan Murid memperhatikan penjelasan singkat dan evaluasi dari guru sebesar 23,53\%, Murid yang mengerjakan soal evaluasi sebesar $23,53 \%$ dan akan dilanjutkan pada siklus II.

\section{Data Hasil Belajar Murid}

Tabel 5 Deskriptif Skor Hasil Belajar PKn pada Siklus I

\begin{tabular}{cc}
\hline Statistik & Nilai Statistik \\
\hline Subyek & 17 \\
\hline Skor tertinggi & 80 \\
\hline Skor terendah & 20 \\
\hline Rentang Skor & 60 \\
\hline Skor rata-rata & 56,47
\end{tabular}

Sumber : Hasil Penelitian Tes Siklus I

Dari tabel 4 menunjukkan bahwa skor tertinggi yang dicapai dari 17 murid adalah 80 , skor terendah 20 , dan skor rata-rata 56,47

Tabel 5 Distribusi Frekuensi Skor Hasil Belajar PKn pada Siklus I

\begin{tabular}{|c|c|c|c|}
\hline Skor & Kategori & Frekuensi & Persentase \\
\hline $84-100$ & Sangat Tinggi & - & - \\
\hline $67-83$ & Tinggi & 5 & 29,41 \\
\hline $50-66$ & Sedang & 7 & 41,17 \\
\hline $33-49$ & Rendah & 3 & 17,64 \\
\hline $16-32$ & Sangat Rendah & 2 & 11,77 \\
\hline \multicolumn{2}{|c|}{ Jumlah } & 17 & 100 \\
\hline
\end{tabular}

Sumber : Hasil Penelitian Tes Siklus I
Pada tabel 5 menunjukkan bahwa 2 murid atau $11,77 \%$ yang nilainya berada dalam kategori sangat rendah, 3 murid atau $17,64 \%$ nilainya berada dalam kategori rendah, 7 murid atau 41,17\% nilainya berada dalam kategori sedang, 5 murid atau $29,41 \%$ nilainya berada dalam kategori tinggi dan tidak ada murid yang berada pada kategori sangat tinggi. Untuk melihat persentase ketuntasan belajar PKn murid kelas IV SD Inpres Boronguntia Kecamatan Bajeng Kabupaten Gowa, setelah diterapkan model pembelajaran Group Investigation pada siklus I dapat dilihat pada tabel berikut ini.

Tabel 6 Deskripsi Ketuntasan Hasil Belajar PKn pada Siklus I

\begin{tabular}{cccc}
\hline Skor & Kategori & Frekuensi & Persentase \\
\hline $\mathbf{0 - 6 4}$ & Tidak Tuntas & 12 & 70,59 \\
\hline 65-100 & Tuntas & 5 & 29,41 \\
& & 17 & 100
\end{tabular}

Sumber : Hasil Penelitian Tes Siklus I

Berdasarkan tabel 4.4 dapat disimpulkan bahwa banyaknya murid yang ketuntasan belajarnya berada pada kategori tidak tuntas sekitar $70,59 \%$ sedangkan murid yang hasil belajarnya berada pada kategori tuntas sekitar $29,41 \%$. Hal ini menunjukkan bahwa pada siklus I ketuntasan hasil belajar secara klasikal belum tercapai karena jumlah murid yang hasil belajarnya tuntas kurang dari $85 \%$.

\section{Hasil Aktivitas Guru}

Hasil aktivitas guru Pada siklus I khususnya pada pertemuan ke-1 dan ke-2, kegiatan berlangsung seperti biasanya, tidak ada perubahan yang berarti dari sebelumnya. Dari langkah-langkah model pembelajaran Group Investigation yang harus disesuiakan oleh guru dalam proses pembelajaran, masih ada yang tidak sesuai dengan langkah-langkah tersebut. Berdasarkan hasil observasi, langkah-langkah yang sudah sesuai meliputi : guru membagi kelas dalam beberapa kelompok heterogen, masing-masing kelompok membahas materi yang sudah ada secara kooperatif yang bersifat penemuan, setelah selesai diskusi juru bicara kelompok menyampaikan hasil pembahasan kelompok, dan evaluasi. Adapun 
langkah-langkah yang belum sesuai meliputi : guru tidak menjelaskan maksud pembelajaran dan tugas kelompok dan guru tidak memanggil ketua kelompok dan setiap kelompok mendapat tugas satu materi/tugas yang berbeda dari kelompok lain, dan guru memberikan penjelasan singkat sekaligus memberikan kesimpulan. Sampai pada pertemuan ke-3 dan ke-4, guru telah menyesuaikan semua langkah-langkah yang harus disesuaikan dalam proses pembelajaran dengan menggunakan model group Investigation yang meliputi : guru membagi kelas dalam beberapa kelompok heterogen, guru menjelaskan maksud pembelajaran dan tugas kelompok, guru memanggil ketua kelompok dan setiap kelompok mendapat tugas satu materi/tugas yang berbeda dari kelompok lain, masing-masing kelompok membahas materi yang sudah ada secara kooperatif bersifat penemuan, setelah selesai diskusi juru bicara kelompok menyampaikan hasil pembahasan kelompok, guru memberikan penjelasan singkat sekaligus memberi kesimpulan, dan terakhir melakukan evaluasi.

\section{Siklus II}

a. Aktivitas Belajar Murid

Aktivitas belajar murid pada siklus II, dimana dari 17 murid kelas IV SD Inpres Boronguntia Kecamatan Bajeng Kabupaten Gowa yang diobservasi terkait aspek-aspek aktivitas belajar, hasilnya dapat dijelaskan dalam skala deskriptif sebagai berikut : Murid yang duduk berkelompok secara heterogen sebesar 23,53\%, Murid yang memperhatikan penjelasan guru sebesar 17,64\%, Ketua kelompok mengambil materi/tugas kelompok yang berbeda dari kelompok lain sebesar 23,53\%, Masing- masing kelompok membahas materi yang sudah ada secara kooperatif dan bersifat penemuan sebesar 23,53\%, Juru bicara kelompok menyampaikan hasil pembahasan kelompok sebesar 17,64\%, Murid memperhatikan penjelasan singkat dan kesimpulan dari guru sebesar 23,53 dan Murid yang mengerjakan soal evaluasi sebesar $23,53 \%$. Adapun grafik aktivitas belajar murid pada siklus II dapat dilihat berikut:

\section{Data Hasil Belajar Murid}

Hasil belajar murid pada mata pelajaran PKn melalui model pembelajaran Group Investigation pada siklus II dapat dilihat pada tabel 4.6 sebagai berikut:

Tabel 6 Deskriptif Skor Hasil Belajar PKn pada Siklus II

\begin{tabular}{cc}
\hline Statistik & Nilai Statistik \\
\hline Subyek & 17 \\
\hline Skor tertinggi & 100 \\
\hline Skor terendah & 53,3 \\
\hline Rentang Skor & 46,7 \\
\hline Skor rata-rata & 86,67
\end{tabular}

Sumber : Hasil Penelitian Tes Siklus II

Dari tabel 6 di atas menunjukkan bahwa skor tertinggi yang dicapai dari 17 murid adalah 100, skor terendah 53,3 dan skor rata-rata 86,67.

Tabel 7 Distribusi Frekuensi Skor Hasil Belajar PKn pada Siklus II

\begin{tabular}{cccc}
\hline Skor & Kategori & Frekuensi & $\%$ \\
\hline $84-100$ & Sangat Tinggi & 5 & 29,41 \\
\hline $67-83$ & Tinggi & 8 & 47,06 \\
\hline $50-66$ & Sedang & 4 & 23,52 \\
\hline $33-49$ & Rendah & - & - \\
\hline $16-32$ & Sangat Rendah & - & - \\
\hline & Jumlah & 17 & 100
\end{tabular}

Sumber : Hasil Penelitian Tes Siklus II

Pada tabel 7 menunjukkan bahwa tak seorang pun murid yang nilainya berada dalam kategori sangat rendah, 3 murid atau 23,52\% nilainya berada dalam kategori sedang dan di nyatakan tidak tuntas karena tidak memenuhi Kriteria Ketuntasan Minimal yang telah di tentukan, 8 murid atau 47,06\% nilainya berada dalam kategori tinggi, 5 murid atau 29,41\% nilainya berada dalam kategori sangat tinggi. Untuk melihat persentase ketuntasan belajar PKn murid kelas IV SD Inpres Boronguntia Kecamatan Bajeng Kabupaten Gowa setelah diterapkan model pembelajaran Group Investigation pada siklus II dapat dilihat pada tabel berikut ini: 
Tabel 8 Deskripsi Ketuntasan Hasil Belajar PKn pada Siklus II

\begin{tabular}{cccc}
\hline Skor & Kategori & Frekuensi & Persentase \\
\hline $\mathbf{0 - 6 4}$ & $\begin{array}{c}\text { Tidak } \\
\text { Tuntas }\end{array}$ & 4 & $\mathbf{2 3 , 5 3}$ \\
\hline $\mathbf{6 5 - 1 0 0}$ & Tuntas & 13 & 76,47 \\
\hline \multicolumn{2}{c}{ Jumlah } & 17 & 100 \\
\hline
\end{tabular}

Sumber : Hasil Penelitian Tes Siklus II

Berdasarkan tabel 8 dapat disimpulkan bahwa banyaknya murid yang ketuntasan belajarnya berada pada kategori tidak tuntas sekitar $23,53 \%$ sedangkan murid yang hasil belajarnya berada pada kategori tuntas sekitar $76,47 \%$.

\section{Hasil Aktivitas Guru}

Hasil aktivitas guru Pada siklus II mulai dari pertemuan ke-1 sampai dengan pertemuan ke-4 sudah sesuai dengan langkah-langkah model Pembelajaran Group Investigation, yang meliputi : guru membagi kelas dalam beberapa kelompok heterogen, guru menjelaskan maksud pembelajaran dan tugas kelompok, guru memanggil ketua kelompok dan setiap kelompok mendapat tugas satu materi/tugas yang berbeda dari kelompok lain, masing-masing kelompok membahas materi yang sudah ada secara kooperatif bersifat penemuan, setelah selesai diskusi juru bicara kelompok menyampaikan hasil pembahasan kelompok, guru memberikan penjelasan singkat sekaligus memberi kesimpulan, dan terakhir melakukan evaluasi. Dengan demikian aktiviats guru yang belum sesuai pada siklus I telah disesuaikan pada siklus II.

\section{Pembahasan Hasil Penelitian}

Hasil analisis penelitian yang dilakukan pada murid kelas IV SD Inpres Boronguntia Kecamatan Bajeng Kabupaten Gowa, dengan menggunakan model pembelajaran Group Investigation, baik hasil belajar murid maupun tingkat keaktifan murid dalam mengikuti pelajaran dari pertemuan ke pertemuan dan dari siklus I ke siklus || pada umumnya dapat meningkat.

Berdasarkan persentase yang dicapai siswa pada setiap akhir pembelajaran pada siklus I, dan siklus II pada akhir tindakan menunjukkan peningkatan yang baik. Hal ini dapat diinterpretasikan bahwa siswa sudah mengalami peningkatan pemahaman terhadap materi mata pelajaran PKn.

Hal ini sejalan seperti yang diungkapkan oleh Clark dalam Angkowo dan Kosasih mengenai hasil belajar (2007:50) mengungkapkan bahwa hasil belajar siswa di sekolah $70 \%$ dipengaruhi oleh kemampuan siswa dan $30 \%$ dipengaruhi oleh lingkungan. Ini menunjukkan faktor internal pada diri siswa lebih dominan dalam mempengaruhi hasil belajar.

Berdasarkan teori di atas bahwa, keberhasilan murid dalam belajar banyak dipengaruhi dari kemampuan murid itu sendiri dalam menerima materi pelajaran dan menyelesaikan soal-soal yang diberikan pada setiap akhir pertemuan dan evaluasi siklus I dan evaluasi siklus II. Pemahaman murid yang baik terhadap materi pelajaran menunjukkan bahwa model pembelajaran Group Investigation memungkinkan dijadikan sebagai salah satu model pembelajaran dalam meningkatkan prestasi siswa dalam mata pelajaran PKn di Sekolah Dasar.

Hal ini terlihat pada hasil belajar murid pada siklus I dengan rata-rata 56,47 dan pada siklus II dapat meningkat dengan rata-rata menjadi 86,67.

Selain terjadi peningkatan kualitas belajar terlihat dari segi hasil terhadap mata pelajaran PKn. Terjadi pula perubahan aktivitas murid dalam proses pembelajaran. Perubahan tersebut merupakan data kualitatif yang diperoleh dari lembar observasi pada setiap pertemuan yang dicatat pada tiap siklus, seperti yang di ungkapkan Mochtar Buchari (1986:94) mengenai hasil belajar adalah hasil yang dicapai atau ditonjolkan oleh anak sebagai hasil belajarnya, baik berupa angka atau huruf serta tindakannya yang mencerminkan hasil belajar yang dicapai masing-masing anak dalam periode tertentu.

Adapun perubahan aktivitas murid yang dimaksud adalah kesiapan murid dalam mengikuti proses belajar mengajar pada siklus I, yaitu $63,1 \%$ meningkat menjadi $79,3 \%$. Hal ini disebabkan oleh murid cenderung tertarik pada materi pelajaran karena pada pembelajaran ini berkaitan langsung 
dengan keseharian murid. Murid yang memperhatikan penjelasan guru mengalami peningkatan pada siklus I, yaitu $60,3 \%$ menjadi $68 \%$ pada siklus II. Hal ini disebabkan karena murid sudah diberikan media gambar yang menarik perhatian karena berhubungan dengan kehidupannya sehari-hari. Murid yang menemukan ide-ide/gagasan dan memberikan tanggapan pada siklus I, yaitu 33,8 menjadi $56,4 \%$ pada siklus II. Hal ini berarti sangat tertarik dan merasa senang dengan pembelajaran yang disajikan karena menambah ide-ide yang belum pernah diketahui. Murid yang berani mengeluarkan pendapatnya meningkat pada siklus I yaitu $42,6 \%$ menjadi $69,2 \%$ pada siklus II. Ini menunjukkan bahwa kemampuan murid terhadap materi cukup dimengerti. Murid yang memperhatikan kelompok lain yang mengemukakan pendapatnya juga mengalami peningkatan dari siklus I yaitu $35,7 \%$ menjadi $63,1 \%$ pada siklus II. Peningkatan ini menunjukkan bahwa murid memahami dengan baik materi yang disajikan sehingga mereka bisa mengaitkan dengan kenyataan sehari-hari. Murid yang dapat menyimpulkan materi juga meningkat dari siklus I yaitu $30,9 \%$ menjadi $59,3 \%$ pada siklus II. Hal ini tentu disebabkan oleh karena perhatian murid pada materi pelajaran cukup paham sehingga murid dapat menyimpulkan materi yang telah dipelajarinya.

Pada pelaksanaan siklus II yang berdasarkan dari hasil observasi siklus II kegiatan guru dan siswa sudah optimal yaitu sudah sesuai dengan langkah-langkah pembelajaran yang di dalam pembelajaran siklus II menunjukkan adanya perubahan yang telah direncanakan sehingga kegiatan dapat terlaksana dengan baik. Dimana lebih baik dari yang sebelumnya karena semua langkah-langkah pembelajaran sudah sesuai dengan model pembelajaran Group Investigation, yang mana apabila model pembelajaran ini diterapkan dengan tepat maka akan terjadi perubahan baik dari segi proses maupun dari segi hasil pembelajaran. Hal ini karena kekurangan di siklus I yang belum tuntas mencapai 12 murid dan tuntas 5 murid sedangkan pada siklus II yang tidak tuntas 4 murid yang tuntas 13 murid dalam mata pelajaran Pendidikan Kewarganegaraan. Murid yang tidak tuntas ada 4 orang diadakan pendekatan untuk mengetahui penyebab ketidak tuntasannya, kemudian diberi bimbingan berdasarkan masalahnya masing-masing kalau berbeda, tapi kalau masalahnya sama diadakan bimbingan kelompok sampai murid tersebut bisa mencapai ketuntasan belajarnya. Akan tetapi sudah dapat dibenahi dengan baik karena pada siklus I guru juga belum semuanya berhasil menerapkan langkahlangkah pembelajaran dengan baik yang sudah dipersiapkan dilembar observasi guru, sehingga ada beberapa juga murid pada siklus I belum mencapai ketuntasan. Kemudian pada siklus II guru berusaha menerapkan langkah-langkah pembelajaran dengan baik yang sudah dipersiapkan dilembar observasi guru sehingga rata-rata murid mencapai ketuntasan belajar karena guru dan murid sudah dapat bersinergi dengan baik di dalam proses belajar mengajar sehingga memperoleh hasil belajar yang signifikan.

\section{KESIMPULAN}

Berdasarkan hasil penelitian dan pembahasan yang telah dikemukakan dapat ditarik kesimpulan bahwa, penerapan model pembelajaran Group Investigation dalam meningkatkan hasil belajar murid di kelas IV SD Inpres Boronguntia Kecamatan Bajeng Kabupaten Gowa dapat ditingkatkan, serta hasil belajar siswa meningkat dari siklus I ke siklus II. Hal ini dapat dilihat dari skor rata-rata siklus I sebesar 56,47 meningkat menjadi 86,67 pada siklus II. Peningkatan ketuntasan belajar murid pada siklus I yaitu $29,41 \%$ meningkat menjadi $76,47 \%$ pada siklus II. Dan penerapan model pembelajaran group Investigation dapat melibatkan murid secara lebih aktif dalam proses pembelajaran. Hal ini ditunjukkan dari peningkatan aktivitas dari siklus I ke siklus II. Aktivitas belajar murid dan aktivitas mengajar guru dalam proses belajar mengajar mengalami peningkatan.

\section{DAFTAR PUSTAKA}

[1] Akwara, Silfanus Wiwi. (2013). Pembelajaran Cooperatife Tipe Group Investigation, (Online), 
(http://slfns.blogspot.com/, diakses Tanggal 02 Juni 2016).

[2] Angkowo, R. dan A. Kosasih. (2007). Optimalisasi Media Pembelajaran. Jakarta: PT. Grasindo

[3] Anshari, Muhammad. (2013). Model Pembelajaran Kooperatif Tipe Group Investigation, (Online), (http://muhammadanshari9.blogspot.com/ 2013/08/model-pembelajaran-kooperatiftipe.html, diakses Tanggal 02 Juni 2016).

[4] Aqib, Zainal. (2013). Model-Model, Media, dan Strategi Pembelajaran Kontekstual (Inovatif). Bandung: Yrama Widya.

[5] Arikunto, Suharsimi, dkk. (2012). Penelitian Tindakan Kelas. Jakarta: Bumi Aksara

[6] Buhari, Mochtar. (1986). Dasar-dasar Kependidikan. Bandung:Tarsito.

[7] Depdikbud. (1994). Kurikulum Pendidikan Dasar. Jakarta: Depdikbud

[8] Depdiknas. (2006). Kurikulum Pendidikan Dasar. Jakarta: Depdikbud.

[9] Dimyati dan Mudjiono. (1999). Belajar dan Pembelajaran. Jakarta: Dirjen Dikti Depdikbud RI

[10] Gagne, Achsin. (1984). Pemanfaatan Media pengajaran.

(Online), (http//www.google.co.id//search=Pemanfaatan Media Pengajaran, diakses Tanggal 02 Juni 2017).

[11] Hamalik, Oemar. (2006). Proses Belajar Mengajar. Bandung.

[12] Hendarto. (1998). Model Pembelajaran. Jakarta: Kencana Perenada Media

[13] Hidayah, Erna. (2012). Peningkatan Hasil Belajar IPS melalui Model Pembelajaran Kooperatif Tipe Group Investigation pada Siswa Kelas IVB SD Negeri Gamol. Skripsi tidak diterbitkan. Yogyakarta: Universitas Negeri Yogyakarta.

[14] JP. Chaplin. (1992). Psikologi Pengajaran. Jakarta: Pustaka Jaya.

[15] Lie,a. (2008). Cooperative Learning: Mempraktekkan Cooperative Learning di Ruang-ruang Kelas. Jakarta: Gramedia Widiasarna Indonesia.

[16] Nasution. (1972). Psikologi Pengajaran Nasional. Bandung: Remaja Rosda Karya.

[71] Pusat Data dan Informasi Pendidikan, BalitbangDepdiknas. (2004). Undang-Undang No.20 Tentang Sisdiknas. Jakarta: Departemen Pendidikan Nasional.

[18] Sabri, Ahmad. (2005). Strategi Belajar Mengajar dan Micro Teaching. Jakarta: Quantum Teaching.

[19] Sanjaya, Wina. (2006). Strategi Pembelajaran. Jakarta: Kencana Prenada Media Group.

[20] Slameto. (2002). Belajar dan Faktor-Faktor yang Mempengaruhinya. Jakarta: Rineka Cipta.

[21] Slavin, R.E. (1995). Cooperative Learning Theory, Research and Practice. Second Edition. Boston: Allyin and Bacon.

[22] Solihatin, E dan Rahardjo. (2007). Cooperative Learning Analisis Model Pembelajaran IPS. Jakarta: Biumi Aksara.
[23] Sudjana, Nana. (2013). Dasar-Dasar Proses Belajar Mengajar. Bandung: Sinar Baru Algesindo.

[24] Suardi, S. (2018). Peningkatan Hasil Belajar Sosiologi Pokok Bahasan Interaksi Sosial Melalui Metode Diskusi pada Siswa Kelas X MA. Muhammadiyah Panaikang Kacamatan Bissappu Kabupten Bantaeng." JURNAL ETIKA DEMOKRASI (JED)" PRODI PPKn FKIP UNISMUH MAKASSAR, 2(1).

[25] Trianto. (2011). Model-Model Pembelajaran Inovatif Berorientasi Konstruktivistik. Jakarta: Prestasi Pustaka Publisher. 